\title{
Shepherd's crook configuration of an early preventricular branch of right coronary artery
}

\author{
Sravan Nagulakonda, ${ }^{1}$ Niraj Nirmal Pandey, ${ }_{1}^{1}$ Sanjeev Kumar, ${ }^{1}$ Sundeep Mishra ${ }^{2}$
}

${ }^{1}$ Cardiovascular Radiology and Endovascular Interventions, All India Institute of Medical Sciences, New Delhi, India ${ }^{2}$ Cardiology, All India Institute of Medical Sciences, New Delhi, India

\section{Correspondence to}

Dr Sanjeev Kumar;

sanjeevradio@gmail.com

Accepted 29 August 2021

\section{DESCRIPTION}

A 58-year-old man with rheumatic mitral and aortic stenosis underwent CT angiography for preoperative evaluation. No coronary atherosclerotic disease was present. Incidentally, an early branching of a large preventricular branch, as the first branch of the right coronary artery (RCA), was noted. The proximal part of preventricular branch was seen coursing cranially above the level of its ostium followed by a 'U-turn' to course caudally and supply the right ventricular myocardium (figure 1).

Shepherd's crook configuration typically involves the main RCA (having a prevalence of 5\%) where the RCA ostium is oriented superiorly and the proximal RCA courses upwards before making a U-turn to enter the right atrioventricular groove. ${ }^{1}$ Percutaneous transluminal angioplasty of lesions in 'Shepherd's crook' RCA poses procedural challenges as steering the hardware across $180^{\circ}$ turn is difficult and results in inferior primary success rates and greater complication rates. ${ }^{2-4}$ This case is unique as instead of RCA, an early preventricular branch is seen to have the 'Shepherd's crook' configuration. Prior knowledge of this variant would prevent it
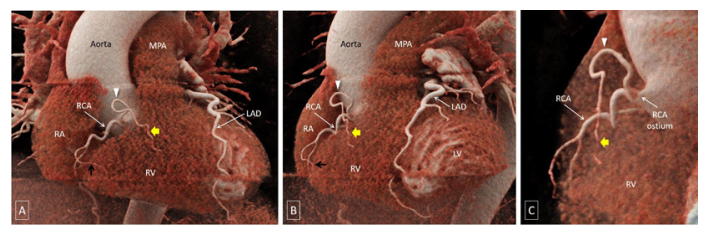

Check for updates

(c) BMJ Publishing Group Limited 2021. No commercial re-use. See rights and permissions. Published by BMJ.

To cite: Nagulakonda S,

Pandey NN, Kumar S,

et al. BMJ Case Rep

2021:14:e246312.

doi:10.1136/bcr-2021-

246312
Figure 1 Volume-rendered images ( $A$ to $C$ ) demonstrate the superiorly directed right coronary artery (RCA) ostium with early origin of a large preventricular branch (thick yellow arrow) from the RCA. The preventricular branch is seen coursing cranially followed by a 'U-turn' (arrowhead) to travel caudally along its expected course supplying the right ventricular (RV) myocardium. The RCA and its acute marginal branch (black arrow) are in their expected locations. RA, right atrium; LAD, left anterior descending artery; MPA, main pulmonary artery; LV, left ventricle.

\section{Learning points}

- Shepherd's crook configuration of a coronary artery is typically described where the ostium is oriented superiorly and the proximal artery travels upwards before making a U-turn to resume its normal course.

- This configuration is most commonly seen involving the right coronary artery, but can also involve its branches.

- Percutaneous transluminal angioplasty of lesions in arteries with Shepherd's crook configuration poses procedural challenges as steering the hardware across the $180^{\circ}$ turn is difficult and results in inferior primary success rates and greater complication rates.

being misdiagnosed as a 'Shepherd's crook' RCA in the event of inadvertent selective cannulation of this early branch.

Contributors All authors participated sufficiently in the conception of the idea, development of the intellectual content, design, writing and final approval of the manuscript.

Funding The authors have not declared a specific grant for this research from any funding agency in the public, commercial or not-for-profit sectors.

Competing interests None declared.

Patient consent for publication Obtained.

Provenance and peer review Not commissioned; externally peer reviewed.

\section{REFERENCES}

1 Gossman DE, Tuzcu EM, Simpfendorfer C, et al. Percutaneous transluminal angioplasty for Shepherd's crook right coronary artery stenosis. Cathet Cardiovasc Diagn 1988;15:189-91.

2 Nesto RW, Sassower MA. PTCA of "shepherd's crook" right coronary arteries with a new shape of guiding catheter. Cathet Cardiovasc Diagn 1993;29:70-3.

3 Shriki JE, Shinbane JS, Rashid MA, et al. Identifying, characterizing, and classifying congenital anomalies of the coronary arteries. Radiographics 2012;32:453-68.

4 Ramsdale DR, Bellamy CM, Grech ED, et al. Early experience of directional coronary atherectomy: clinical results, complications and histopathological findings. Int J Cardiol 1994;43:127-37. 
Copyright 2021 BMJ Publishing Group. All rights reserved. For permission to reuse any of this content visit https://www.bmj.com/company/products-services/rights-and-licensing/permissions/

BMJ Case Report Fellows may re-use this article for personal use and teaching without any further permission.

Become a Fellow of BMJ Case Reports today and you can:

- Submit as many cases as you like

Enjoy fast sympathetic peer review and rapid publication of accepted articles

Access all the published articles

Re-use any of the published material for personal use and teaching without further permission

Customer Service

If you have any further queries about your subscription, please contact our customer services team on +44 (0) 2071111105 or via email at support@bmj.com.

Visit casereports.bmj.com for more articles like this and to become a Fellow 